\title{
Dividend Announcement and Abnormal Return :An Applied Study on Banking Shareholding Firms in Amman Bourse
}

\author{
Dr.Mousa Saeed Matar \\ Instructor Of Finance And Banking Department. \\ Al-Ballquqa Applied University
}

\begin{abstract}
This study aims to test the effect of dividend announcement on stock prices on banking shareholding companies, and investigating the information content of this announcement on either stock prices and trading volumes. it is also aims to investigate the ability of investors to earn abnormal return by using these information. The behaviour of stock prices is studied on the basis of monthly or weekly movements. On this paper an attempt was made to analyze the daily stock prices of banking shareholding companies listed in Amman bourse using CAPM model in order to estimate the normal return and the percentage change of daily stock prices in order to estimate the actual return. The hypothesizes of the study were examined by using parametric tests as one-sample test and paired sample to test. it was found that there was no information content to these dividends' announcements on stock prices and investors couldn't neither use information to beat the market nor earning abnormal return .This study can be a source of help to market makers to improve either way of timing their decision to buy and sell stocks or the way of analyzing dividend announcement content . and it is also a source of help to potential and current investors to improve their understanding and reading of these announcements .

Keywords:return(excess return),normal: dividend announcements ,stock prices, abnormal return ,CAPM,under reaction, over reaction

DOI: $10.7176 /$ RJFA/10-18-03

Publication date:September $30^{\text {th }} 2019$

\subsection{Introduction}

Dividend announcements is considered as a key instrument for information used to make financial decisions by market makers and investment institutions, creditors and investors because it has a multi information content for those groups .

Dividend announcements provide key information for current and potential investors ,creditors and many others to make rational decisions related to their portfolios ; annual dividend announcements contains a lot of information which may change market makers strategies related to a specified stock or portfolio and as a result may affect trading volume. As dividend announcements are public information and available for all investors, this study is an attempt to find the effect of these announcements on stock prices and the ability to earn abnormal return (excess return). this mean it is is a testing efficiency of Amman bourse at semi strong .
\end{abstract}

\subsection{Importance of the study:}

Testing the efficiency of markets in general and Amman bourse in specific terms will provide many market makers and institutional investors either - current or anticipated - with information about the suitable strategies for investing in these markets according to their level of efficiency. As capital markets are working beyond strong level of efficiency, then the monopolistic information will not exist and no one can earn excess return in comparison with other investors .

Also this study is expected to make contributions in three fields : first to know the information content of dividend announcements and the effect of these information on both institutional investors and market makers behavior. secondly establishing new investment strategies to meet investors goals. Third: contributions to the academic fields by providing a new perspective in finding out the efficiency of Amman bourse from this study , the academic fields will be able to gain better understanding in the interaction between the information content and efficiency of markets .

\subsection{Objective of the study :}

The main objectives of the study

1- to examine the semi strong efficiency g in Amman bourse using dividend announcements as a surprise event.

2- to clarify the factors that -affect the efficiency of markets at semi strong .

3- to identify the obstacles and difficulties facing intuitional investors and market makers in Amman bourse .

\subsection{Problem statement :}

this study is intended to examine the following three major hypothesis according to efficiency market hypothesis: First, it is expected that stock prices will response rapidly and simultaneously to dividend announcements or any 
new information second: Investors couldn't earn abnormal by using these information.

\section{5 literature review :}

According to omet (1997), Amman bourse has to improve its policies and techniques in order to attract more investments and to increase liquidity in the stock market.

Roll (1997) compared the risk- adjusted return for small Companies with large companies during (19621997) he found that annual yields for small size companies outperferform large size companies with a rate of $12 \%$ with even risk for the two groups .

Ghilani (1995) has found the bourse of Omman wasn't t efficient at week level because historical data didn't influence on stock shares and there was an opportunity to earn excess returns .

Musa (2001)he company size has no significant impact on stock return either if we use the book value or market value as a measure of size while the existence of size impact was found before the return was adjusted with risk. There was no difference between risks of portfolios consisting of small size or large size companies .

Ghilani (1995), there no evidence of efficiency at the week form level in Omman market and historical information didn't be reflect on stock prices and the stock prices didn't have the characteristics of normal distribution .

Lonie (1996) the firms with high EPS and DPS had earned Excess returns while those with low EPS and DPS had earned abnormal loss.

Beaver (1998) the annual financial reports had trading volumes, also the investor modified his portfolio to keep up with these information .

\subsection{Methodology :}

To achieve the main objectives of this research, the data for this study was gathered from secondary sources the daily closing prices of stocks as published in Amman bourse 2010-2018before and after dividend announcement .These data were used to compute normal returns and abnormal returns of the selected Jordanian companies for the mentioned period, as well as to assess the efficiency of markets .

Dominant banking firms were selected as a sample of the study which it accounts $33 \%$ of the study population However the dependent variable of this study will be the stock returns which will be measured by the the percentage change of actual daily stock prices; independent variable is the return of market portfolio which will be measured by the percentage change of Amman Bourse financial indicator .

For the purpose of analysis this a study uses The CAPM to estimate the normal return and the variance between actual return and expected return to estimate the excess return. the paired sample test and ANOVA was used in testing the hypotheses and to measure the difference between abnormal return before and after the event. Pearson correlation coefficient also used to investigate the correlation between the two variables at $5 \%$ level of confidence according to the SPSS software package .

\subsection{Results and Analysis :}

\subsubsection{Analysis}

Table shows the average normal return and accumulated average abnormal return for companies involved in the study sample before and after the event (25days before and 25 days after the event ):

\begin{tabular}{|l|l|l|l|}
\hline Serial & Days before $\backslash$ after & Average abnormal return & Accumulative average abnormal return \\
\hline 1 & 25 & & \\
\hline 2 & 24 & 0.00777 & 0.00777 \\
\hline 3 & 23 & 0.000222 & 0.01299 \\
\hline 4 & 22 & 0.00332 & 0.02278 \\
\hline 5 & 21 & 0.007651 & 0.03229 \\
\hline 6 & 20 & 0.01222 & 0.04328 \\
\hline 7 & 19 & 0.00302 & 0.05229 \\
\hline 8 & 18 & 0.00429 & 0.06779 \\
\hline 9 & 17 & 0.00172 & 0.07350 \\
\hline 10 & 16 & 0.00742 & 0.08092 \\
\hline 11 & 15 & 0.00615 & 0.008807 \\
\hline 12 & 14 & 0.00206 & 0.09373 \\
\hline 13 & 13 & 0.00113 & 0.09988 \\
\hline 14 & 12 & 0.00798 & 0.10548 \\
\hline 15 & 11 & 0.00140 & 0.11324 \\
\hline 16 & 10 & 0.01830 & 0.12691 \\
\hline 17 & 9 & 0.00266 & 0.13895 \\
\hline
\end{tabular}




\begin{tabular}{|c|c|c|c|}
\hline Serial & Days before $\backslash$ after & Average abnormal return & Accumulative average abnormal return \\
\hline 18 & 8 & 0.00133 & 0.14260 \\
\hline 19 & 7 & 0.00555 & 0.14914 \\
\hline 20 & 6 & 0.00637 & 0.12691 \\
\hline 21 & 5 & 0.00323 & 0.16329 \\
\hline 22 & 4 & 0.00432 & 0.17230 \\
\hline 23 & 3 & 0.00022 & 0.18088 \\
\hline 24 & 2 & 0.00321 & 0.18922 \\
\hline 25 & 1 & 0.00051 & 0.19682 \\
\hline 26 & 0 & 0.00021 & 0.20933 \\
\hline 27 & 1 & 0.00231 & 0.21801 \\
\hline 28 & 2 & 0.0231 & 0.23259 \\
\hline 29 & 3 & .00438 & 0.23885 \\
\hline 30 & 4 & 0.00232 & 24755 \\
\hline 31 & 5 & .000211 & 0.24755 \\
\hline 32 & 6 & .00269 & 0.26520 \\
\hline 33 & 7 & 0.0009871 & 0.27112 \\
\hline 34 & 8 & 0.00213 & 0.27828 \\
\hline 35 & 9 & 0.00654 & 0.28589 \\
\hline 36 & 10 & 0.00098 & 0.29282 \\
\hline 37 & 11 & 0.00437 & 0.30414 \\
\hline 38 & 12 & 0.00706 & 0.31120 \\
\hline 39 & 13 & 0.00432 & 0.31786 \\
\hline 40 & 14 & 0.00653 & 0.32427 \\
\hline 41 & 15 & .002140 & 0.33136 \\
\hline 42 & 16 & .00767 & 0.33903 \\
\hline 43 & 17 & .000802 & 0.34690 \\
\hline 44 & 18 & .00946 & 0.35636 \\
\hline 45 & 19 & 0.01607 & 0.37243 \\
\hline 46 & 20 & 0.00235 & 0.38121 \\
\hline 47 & 21 & 000878 & 0.39015 \\
\hline 48 & 22 & 0.00123 & 0.39969 \\
\hline 49 & 23 & 0.001288 & 0.40697 \\
\hline 50 & 24 & 0.00700 & 0.41582 \\
\hline
\end{tabular}

Source :computed from Amman stock exchange using daily closing, 2011 table shows the window dressing which consist of 25 day before the event, 25 after the event in addition to the event day (day o) and provides the average abnormal return for the all selected companies and the accumulative average abnormal return .

Moreover table indicates that these was an existing of positive abnormal return during the window dressing and an increasing of accumulative average abnormal return during the period surrounding the event .

Testing : the decision rule, accept ho if calculated hypotheses value is less than tabulated value and reject ho if calculated value is greater.

This study proposes 3 hypotheses : the first one stated that the sum of daily abnormal return at the day of dividend announcements didn't differ from zero.

this hypothesis was examined using one sample t-test and it was

\begin{tabular}{|l|l|l|l|}
\hline Mean & t-calculated & t-tabulated & Result of ho \\
\hline $0,00053-$ & $1,908-$ & 1,9818 & Reject \\
\hline
\end{tabular}

found that (calculated $\mathrm{t}=1.708$ ) is smaller than (tabulated $\mathrm{t}=1.91818$ ) according to decision rule this hypothesis is rejected and we can state that there is a positive abnormal return at the event day (the day of publishing financial statement ) .

Hypothesis 1-2 :

Ho : prices dont adjust rapidly to dividend annoucements

Hypothesis (1-2)

Table (3)

Test of hypothesis(1-2)

\begin{tabular}{|l|l|l|l|l|}
\hline Mean residual & T calculate & tabulated & Sig. & Result of ho \\
\hline 0.00093 & 1.222 & 1.9818 & 0.08 & Accept \\
\hline
\end{tabular}

This study was examined using paired sample test, it is found that there is no statically difference between 
pre and post mean which ascertain that there is no information content to that event dividend announcements . 1.7.2 Results

After analyzing the data and testing the hypothesis the following results were extracted :

1 -it was found that the sum of daily excess return at the day of dividend announcement doesn't differ from zero. This result doesn't ignore the of excess return at the event day, but some companies earn excess loss and others earn excess return and the sum of excess return and excess loss doesn't differ from zero ( abnormal return has deleted when we add abnormal loss )

2- the sum of absolute abnormal return at the day of dividend announcement differ from zero and these excess return ascertain the inefficency of Amman bourse .

3 - we can use the event of dividend announcement in earning abnormal returns this result doesn't' $t$ ignore the existence of excess return but the average of excess return before and after dividend announcement doesn't differ . 4- according to the stock prices responsiveness to new information,we can describe that process as very slowly because of the existence of abnormal return during the days following the event .

5-there is a delay in stock prices response to dividend announcement which is seemed by the existence of excess return during the period surround the event : this is ascertain that dividend announcements has an information content but the process of generating abnormal return ascertain the delay of adjusting prices to that event and the undereaction response.

\subsection{References:}

1. A. Lonic , G. Abey Ranta, The Stock Market Reaction to the divided Announcement" , Journal of Economic Studies, vol. 23 No. 1, 1996 ,p. 135.

2. Bamber, Linda Smith, "The Information Content of Annual Earning Releases" , A Trading Volumes Approach, The accounting Review, 1987 , pp. 67-92 .

3. Bettis , J., Kim , "The Effect of Trading Halts on Bid Ask Spreed and Transaction Price" , Journal of Finance, vol. 8 , No. 4, 1998 , p. 131 .

4. Bodie , Z., "Common Stocks as a Hedging Against Inflation" , Journal of Finance , vol. 1, No. 5 , 1976.

5. Condoyamni , L. et. al., "Week and Effects on Stock Market Returns" International Evidence , Dimsan Stock Market Anomalies Cambridge University, 1998 , pp. 226-238 .

6. Charest, Guy , "Dividend information”, Stock Return , and Market efficiency , Journal of financial Economics , USA, vol. 6 , No. 3 , 1978 , pp. 297-330 .

7. Cumby , R. \& Glen, J., "Evaluating Performance of International Mutual Funds", Journal of Finance , , USA, vol. 9 , No. 5 , 2000 , p. 497 .

8. Fama , "Market Efficiency , Long - Term Returns and Behavioral Finance" , Journal of Financial Economics, USA, vol. 8 , NO. 49 , 1988 , p. 284.

9. Fama , Eugne , "Efficient Capital Market", A Review of Theory and Empirical Work, Journal of Finance , USA, 1970 , p. 383 .

10. Fama , E. f., “The Behavior of Stock Market Price”, Journal of business , USA, vol. 38 No. 5 , 1965 , pp. 34-105.

11. Fish R., Gosnell T. \& Lasser , J., Dehnies , “The Monday effect”, Journal of Finance , USA, 1993 , pp. 123 125 .

12. Fridson M. , \& Candia A. Trends , "Follow , Buke , or Igrove", Journal of Portfolio Management , vol. 8 , No. 19,1991 , pp. 50-55 .

13. Kawakatsu , Hiroyuki \& Morey , "Financial Liberalization and Stock Market efficiency" , An empirical Examination of nine emerging Countries, Jordan of Multinational Financial Management, vol. 2 , No. 9 , 1999 , pp. 353-371.

14. Keim , Donald B. , "Size Related Anomalies and Stock Return Seasonality", For the empirical evidence , Journal of Financial Economics, vol. 111 , No. 1, 1987 , pp. 13-32 .

15. Miller , R., \& Reily , F., “An Examination of Mispricing Return and Uncertainty for initial publick offerings", financial management, New York, vol. 8 , No. 2 , 2000 , pp. 22-23 j.

16. Omet Ghassan, "The Jordanian Stock Exchange" :Prospects and challenges , Derasat , University of Jordan , vol. 26 , No. 1 , 1999 , pp. 132-139.

17. Omet Ghassan, "Stock Market Seasonality" : Evidence from the Amman financial market, University of Jordan, derasat, 1991 , pp. 320-333 .

18. Omet Ghassan, "Evidence from the Amman Financial Market", university of Jordan , Derasat, 1991 , pp. 420-445.

19. Paradeep , K., \& Perter F. Pope , “Intraweek and Intraday Seasons”, Journal of Finance , vol.3 , No. 7 , 1992 , pp. 233-270.

20. Radcliffe, R., “Investment Concepts ANALYSIS AND Strategy”, USA, Foreman \&Comp. , 1982 , p. 320 .

21. Reiganum , R., Marc , “A Direct Test of Roll's Conjecture of the Firm Size Effect”, Journal of Finance , 
USA, vol. 216 , No. 1 , 1982 , pp. 27-35 .

22. Roll R., “A possible Explanation of the Small Firm Effect”, Journal of Finance, USA, vol. 213 , No. 3 , 1995 , pp. $879-888$.

23. Ross , L., watts , "Systematic Abnormal Return After Quarterly Earmomg Ammpimce,emts", Journal of financial Economics, USA, vol. 3 , No. 6 , 1978 , pp. 127-150 .

24. Sorensen, E., and Burke T., "Portfolio Return from Active Industry Group Rotation”, Financial Analysts Journal, USA, vol. 7 , No. 42,1986, p.43.

25. William , H., Beaver, "The Information Content of Annual Earnings Announcement" Journal of Accounting Research, USA, vol. 2 , 1998 , pp. 68-69. 